\title{
Stem and Total Above-Ground Biomass Models for the Tree Species of Freshwater Wetlands Forest, Coastal Areas and Dry Areas of Bangladesh: Using a Non-Destructive Approach
}

\author{
Mahmood Hossain $^{1^{*}}$ (D), Chameli Saha1 ${ }^{(\mathbb{D},}$, Rakhi Dhali1, Srabony Saha ${ }^{1}$, \\ Mohammad Raqibul Hasan Siddique1, S. M. Rubaiot Abdullah', S. M. Zahirul Islam² \\ ${ }^{1}$ Forestry and Wood Technology Discipline, Khulna University, Khulna, Bangladesh \\ ${ }^{2}$ Research Officer, Forest Inventory Division, Bangladesh Forest Research Institute, Chittagong, Bangladesh \\ Email: *mahmoodhossain@hotmail.com, chamelifwt@gmail.com, rakhidhali95@gmail.com, srabonysaha.ku15@gmail.com, \\ raqibulhasan_fwt@yahoo.com, rubaiot@yahoo.com,zahir.fid.bfri@yahoo.com
}

How to cite this paper: Hossain, M., Saha, C., Dhali, R., Saha, S., Siddique, M. R. H., Abdullah, S. M. R., \& Islam, S. M. Z. (2021). Stem and Total Above-Ground Biomass Models for the Tree Species of Freshwater Wetlands Forest, Coastal Areas and Dry Areas of Bangladesh: Using a Non-Destructive Approach. Open Journal of Forestry, 11, 73-82.

https://doi.org/10.4236/ojf.2021.112006

Received: February 17, 2021

Accepted: March 30, 2021

Published: April 2, 2021

Copyright ( 2021 by author(s) and Scientific Research Publishing Inc. This work is licensed under the Creative Commons Attribution International License (CC BY 4.0).

http://creativecommons.org/licenses/by/4.0/ (c) (i) Open Access

\begin{abstract}
Biomass and carbon stock in a forested areas are now prime important indicators of forest management and climate change mitigation measures. But the accurate estimation of biomass and carbon in trees of forests is now a challenging issue. In most cases, pantropical and regional biomass models are used frequently to estimate biomass and carbon stock in trees, but these estimations have some uncertainty compared to the species-specific allometric biomass model. Acacia nilotica, Casuarina equisetifolia and Melia azedarach have been planted in different areas of Bangladesh considering the species-specific site requirements. While Barringtonia acutangula and Pongamia pinnata are the dominant tree species of the freshwater swamp forest of Bangladesh. This study was aimed to develop species-specific allometric biomass models for estimating stem and above ground biomass (TAGB) of these species using the non-destructive method and to compare the efficiency of the derived biomass models with the frequently used regional and pantropical biomass models. Four Ln-based models with diameter at breast height (DBH) and total height $(\mathrm{H})$ were tested to derive the best fit allometric model. Among the tested models, Ln (biomass) $=\mathrm{a}+\mathrm{b} \operatorname{Ln}(\mathrm{D})+\mathrm{c} \operatorname{Ln}(\mathrm{H})$ was the best-fit model for $A$. nilotica, $M$. azedarach, $B$. acutangula and $P$. pinnata and Ln (biomass) $=\mathrm{a}+\mathrm{b} \operatorname{Ln}\left(\mathrm{D}^{2} \mathrm{H}\right)$ was best-fit for $C$. equisetifolia. Finally, the derived best-fit species-specific TAGB models have shown superiority over the other frequently used pantropical and regional biomass models in relation to model efficiency and model prediction error.
\end{abstract}




\section{Keywords}

Allometry, Biomass, Freshwater Wetlands, Coastal Areas, Dry Areas

\section{Introduction}

Bangladesh is facing rapid deforestation and fragmentation of natural forest to meet the basic needs of the additional population as in the rest of the world, which results in only $12.8 \%$ forest cover of the total country area (GoB, 2019). However, the natural forest area declined rapidly, but the overall tree canopy coverage increased modestly from 2000 to 2014 in Bangladesh (Potapov et al., 2017). This improvement has been made possible due to the overall progress of the afforestation programs across the country. Acacia nilotica, Barringtonia acutangula, Casuarina equisetifolia, Melia azedarach and Pongamia pinnata have been planted in various zones of the country considering the species-specific site requirements. Barringtonia acutangula and $P$. pinnata are the dominant native naturally growing tree species of the freshwater wetland (Ratargul swamp forest) and also found in other marshy lands of Bangladesh as plantation (Hossain, 2015; FAO, 2018). Casuarina equisetifolia is native to the southern Bangladesh and $A$. nilotica is an introduced species, but both are suitable for plantation in sandy coastal lands and slop of coastal embankment. Moreover, A. nilotica is also promising for roadside plantation (Nandy et al., 2002; Siddiqi, 2002; Islam et al., 2014; Hossain, 2015; GoB, 2019). Melia azedarach is an exotic species which is planted for roadside avenue trees in dry areas and also in hill zones in Bangladesh (Das \& Alam, 2001; Hossain, 2015; GoB, 2019).

These species are planted all over the country to increase the green cover, road and embankment stabilization, which ultimately contributed to the climate change mitigation initiatives of Bangladesh. The contribution of these species in carbon locking is needed to assess their role in climate change mitigation measures. In this situation, development of species-specific biomass estimation models could open new windows in understanding the carbon stocking and sequestration, nutrient cycling, site productivity, and sustainable management of them. Among the diverse methods of biomass estimation, pantropical allometric biomass models are available. But, there are some restrictions for using these pantropical biomass models (Mahmood et al., 2019a, 2019b, 2019c). Variation of biomass estimation may even greater when used the same model in different geographic locations and this variation may be due to difference in climatic conditions, site quality, forest types and tree architecture (Brown et al., 1989; Ter-Mikaelian \& Korzukhin, 1997; Chave et al., 2005; Návar, 2009; Genet et al., 2011). However, site and species-specific allometric biomass models provide greater accuracy in assessing the biomass and carbon stock than regional and pantropical equations (Ketterings et al., 2001; Chave et al., 2005; Mahmood et al., 2019a, 2019b, 2019c, 2020). While, A. nilotica and M. azedarach have only 
the allometric volume models (Latif \& Islam, 2014) and M. azedarach has species-specific allometric biomass models for the limited geographical areas of Bangladesh (Miah et al., 2020). So, species specific allometric biomass models for A. nilotica, B. acutangula, $C$. equisetifolia, $M$. azedarach and $P$. pinnata are needed for accurate estimation of biomass and carbon stock assessment. Therefore, present was aimed to 1) develop species-specific allometric biomass models for estimating stem and above ground biomass of the studied species ( $A$. nilotica, B. acutangula, $C$. equisetifolia, $M$. azedarach and $P$. pinnata) using the non-destructive approach and 2) compare the efficiency of the derived biomass models with the frequently used regional and pantropical biomass models.

\section{Materials and Methods}

\subsection{Selection of Sample Trees}

Present study collected two sets of data for each species which were denoted as data set A and B. The data set A that was collected at the first stage for each species was deployed to derive the biomass models, while the dataset B of each species was collected separately to validate the derived allometric biomass models. The sample trees of this study were selected purposively to avoid defective, disease affected, top broken and suppressed one. A total of 92 and 123 sample trees of A. nilotica, and C. equisetifolia were collected from the coastal areas of Bangladesh covering coastal block plantation, roadside and embankment plantation. Sample trees of $B$. acutangula (307 individuals), and P. pinnata (261 individuals) were collected from the only one natural freshwater swamp forest (Ratargul swamp forest) situated at the northeastern part of Bangladesh. While, 123 individuals of $M$. azedarach were sampled from the plantations situated at the northern part of Bangladesh. The wood density, range of DBH (Diameter at Breast Height), range of tree height and number of individuals in each dataset have been presented in Table 1.

\subsection{Tree Measurement}

DBH and total height $(\mathrm{H})$ of the sampled trees were was measured by using

Table 1. List of studied species and their wood density (Source: Zanne et al. (2009)), range of DBH and Height, sample number in data set A and B and mean biomass expansion factor. Wood density.

\begin{tabular}{|c|c|c|c|c|c|c|}
\hline Name of species & Family & $\begin{array}{l}\text { Average wood } \\
\text { density (g/cc) }\end{array}$ & $\begin{array}{c}\text { Range of } \\
\text { DBH } \\
(\mathrm{cm})\end{array}$ & $\begin{array}{l}\text { Range of } \\
\text { Height } \\
\text { (m) }\end{array}$ & $\begin{array}{c}\text { Dataset } \\
\text { A }\end{array}$ & $\begin{array}{c}\text { Dataset } \\
\text { B }\end{array}$ \\
\hline Acacia nilotica & Fabaceae & $0.723 \pm 0.052$ & $9.8-40$ & $7.0-15.5$ & 67 & 25 \\
\hline Melia azedarach & Meliaceae & $0.438 \pm 0.021$ & $7.4-34$ & $4-13.5$ & 100 & 23 \\
\hline Barringtonia acutangula & Lecythidaceae & $0.525 \pm 0.167$ & $9.5-42$ & $2.5-8.5$ & 250 & 57 \\
\hline Casuarina equisetifolia & Casuarinaceae & $0.809 \pm 0.03$ & $9.5-43$ & $8-28.5$ & 240 & 52 \\
\hline Pongamia pinnata & Fabaceae & $0.595 \pm 0.02$ & $9.8-46.3$ & $5.5-15$ & 210 & 51 \\
\hline
\end{tabular}


diameter tape and haga altimeter respectively. The sampled trees were climbed to measure the sectional (suitable log sections) diameter of stems and the bigger branches (Diameter $>10 \mathrm{~cm}$ ) using a diameter tape or caliper according to Picard et al. (2012).

\subsection{Biomass of Sample Trees}

Sectional volume of stem and bigger branch of individual sampled trees were estimated using Smalian's formula (Equation (1)) and volumes of each log section were summed to get the total volume of that particular sampled tree.

$$
\text { Smalian's formula }(V)=\frac{\pi L\left(D_{1}^{2}+D_{2}^{2}\right)}{8}
$$

where, $V=$ volume in $\mathrm{m}^{3}, \pi=3.143, L=$ Length of the log section $(\mathrm{m}), D_{1}=$ Diameter at the thicker end (m), $D_{2}=$ Diameter at the thinner end $(\mathrm{m})$.

Finally, the biomass of stem and bigger branch biomass $(\mathrm{kg})$ of the individual sampled tree was estimated from their stem volume $\left(\mathrm{m}^{3}\right)$ and wood density (W) $(\mathrm{g} / \mathrm{cc})$ value of the respective tree species as collected from wood density database generated by Zanne et al. (2009) (Table 1). Wood density varies along the length from base to top of the stem and bigger branches. Moreover, it also varies from the periphery to the pitch of the stem and branch and age of the tree (Picard et al., 2012). This study did not consider this variation in wood density. Therefore, biomass estimates from this study have a certain level of uncertainties. Other sources of uncertainty also exist in the calculation of total Above-ground biomass (TAGB). TAGB of trees included the biomass of stem and bigger branches, smaller branches, and leaves. But, the calculation of TAGB for this study did not include the biomass of smaller branches (diameter $<10 \mathrm{~cm}$ ) and leaves of the sampled trees, which was a source of underestimation.

\subsection{Allometric Model Development and Evaluation}

The independent variables ( $\mathrm{DBH}$ and $\mathrm{H})$ and dependent variable stem biomass and total above ground biomass (TAGB) were transformed to Ln (natural logarithm) to improve the linearity and homoscedasticity. Four Ln based models were tested to derive the best fit allometric model for TAGB and stem biomass: Model 1) $\ln$ (biomass) $=a+b \ln (D)$; Model 2) $\ln$ (biomass) $=a+b \ln (H)$; Model 3) $\ln$ (biomass) $=a+b \ln \left(D^{2} H\right)$; Model 4) $\ln ($ biomass $)=a+b \ln (D)+c \ln (H)$. All the tested models were natural logarithm which introduced a systematic bias during biomass estimation. Therefore, a correction factor (CF) was calculated for each equation to minimize the systematic bias during the back transformation to biomass value (Sprugel, 1983). The best-fitted models were selected based on the lowest Akaike Information Criterion Corrected (AICc), Residual Standard Error (RSE), Standard Error of Equation (SEE) and the highest coefficient of determination (Adjusted $\mathrm{R}^{2}$ ) values (Sileshi, 2014; Mahmood et al., 2019a, 2019b, 2019c). Data was analyzed using R statistical software. Microsoft Office Excel 2016. The derived best-fitted TAGB models were 
compared and evaluated with the frequently used regional and pantropical models (Table 2) in terms of Model Efficiency (ME) and Model Prediction Error (MPE) (Mayer and Butler, 1993). This comparison was conducted with dataset B.

$$
\begin{gathered}
\operatorname{MPE}(\%)=\frac{100}{n} \times \sum\left[\frac{\left(Y_{p}-Y_{o}\right)}{Y_{o}}\right] \\
\mathrm{ME}=1-\left[\frac{\sum\left(Y_{o}-Y_{p}\right)^{2}}{\sum\left(Y_{o}-\bar{Y}\right)^{2}}\right]
\end{gathered}
$$

where, $n=$ Number of trees, $Y_{p}=$ Predicted biomass from model, $Y_{o}=$ Observed biomass in field measurement and $\bar{Y}=$ Mean of the observed biomass.

\section{Results}

\subsection{Selection of Allometric Model}

In case of stem and TAGB, Model $4(\ln ($ biomass $)=a+b \ln (D)+c \ln (H))$ selected as best-fit for $A$. nilotica, $M$. azedarach, $B$. acutangula and $P$. pinnata. While, Model $3\left(\ln (\right.$ biomass $\left.)=a+b \ln \left(D^{2} H\right)\right)$ has been selected as best-fit for stem and TAGB of Casuarina equisetifolia. The range of adjusted $\mathrm{R}^{2}$ for the best-fitted models of stem and TAGB were 0.904 to 0.974 and 0.886 to 0.975 respectively, which were quite good fit (Table 3 and Table 4).

Table 2. Regional and commonly used pan-tropical allometric biomass models.

\begin{tabular}{ccc}
\hline Source & Allometric biomass model & Type \\
\hline $\begin{array}{c}\text { Mahmood et al., 2019a } \\
\text { (Tropical moist deciduous forest) } \\
\text { Brown et al. (1989) (Moist) }\end{array}$ & $\ln ($ TAGB $)=-2.460+2.171 * \ln (D)+0.367 * \ln (H)+0.161 * \ln (W)$ & $\begin{array}{c}\text { Regional multi-species, } \\
\text { Bangladesh }\end{array}$ \\
Chave et al. (2005) & TAGB $=\exp \left(-2.4090+0.9522 * \ln \left(D^{2} * H * W\right)\right)$ & Pan-tropical \\
Chave et al. (2014) & TAGB $=\exp \left(-2.977+\ln \left(D^{2} * H * W\right)\right)$ & Pan-tropical \\
Nelson et al. (1999) & TAGB $=\exp \left(-2.6986+0.976 \ln \left(D^{2} * H * W\right)\right)$ & Pan-tropical \\
\hline
\end{tabular}

\begin{tabular}{|c|c|c|c|c|c|c|c|c|c|}
\hline Species & Equation & $a$ & $b$ & $c$ & $\begin{array}{c}\text { Adjusted } \\
\qquad \mathbf{R}^{2}\end{array}$ & RSE & SEE & AICc & $\begin{array}{c}\text { Correction } \\
\text { Factor }\end{array}$ \\
\hline Acacia nilotica & $\ln ($ biomass $)=a+b * \ln (D)+c * \ln (H)$ & -2.256 & 2.011 & 0.388 & 0.958 & 0.033 & 0.185 & -216.363 & 1.017 \\
\hline Melia azedarach & $\ln ($ biomass $)=a+b * \ln (D)+c * \ln (H)$ & -2.378 & 1.782 & 0.143 & 0.922 & 0.033 & 0.183 & -330.248 & 1.017 \\
\hline Barringtonia acutangula & $\ln ($ biomass $)=a+b * \ln (D)+c * \ln (H)$ & -1.857 & 1.631 & 0.461 & 0.904 & 0.035 & 0.183 & -839.985 & 1.017 \\
\hline Casuarina equisetifolia & $\ln ($ biomass $)=a+b * \ln \left(D^{2} * H\right)$ & -2.395 & 0.866 & & 0.974 & 0.017 & 0.13 & -970.019 & 1.008 \\
\hline Pongamia pinnata & $\ln ($ biomass $)=a+b * \ln (D)+c * \ln (H)$ & -1.379 & 1.486 & 0.475 & 0.925 & 0.021 & 0.146 & -797.591 & 1.011 \\
\hline
\end{tabular}

Table 3. Best fit models for stem biomass.

Note: $\mathrm{R}^{2}=$ co-efficient of determination; RSE = Residual Standard Error; SEE = Standard Error of Equation; AICc $=$ Akaike Information Criterion corrected; $\mathrm{CF}=$ Correction factor. 
Table 4. Best-fit models for Total above-ground biomass.

\begin{tabular}{|c|c|c|c|c|c|c|c|c|c|}
\hline Species & Equation & $a$ & $b$ & $c$ & $\begin{array}{c}\text { Adjusted } \\
\mathbf{R}^{2}\end{array}$ & RSE & SEE & AICc & $\begin{array}{c}\text { Correction } \\
\text { Factor }\end{array}$ \\
\hline Acacia nilotica & $\ln ($ biomass $)=a+b * \ln (D)+c * \ln (H)$ & -3.005 & 2.099 & 0.652 & 0.965 & 0.032 & 0.180 & -219.525 & 1.016 \\
\hline Melia azedarach & $\ln ($ biomass $)=a+b * \ln (D)+c * \ln (H)$ & -2.350 & 1.799 & 0.117 & 0.916 & 0.036 & 0.191 & -321.508 & 1.018 \\
\hline Barringtonia acutangula & $\ln ($ biomass $)=a+b * \ln (D)+c * \ln (H)$ & -1.287 & 1.668 & 0.485 & 0.900 & 0.038 & 0.192 & -814.885 & 1.019 \\
\hline Casuarina equisetifolia & $\ln ($ biomass $)=a+b * \ln \left(D^{2} * H\right)$ & -2.669 & 0.9 & & 0.975 & 0.017 & 0.131 & -966.306 & 1.009 \\
\hline Pongamia pinnata & $\ln ($ biomass $)=a+b * \ln (D)+c * \ln (H)$ & -1.167 & 1.574 & 0.314 & 0.886 & 0.035 & 0.187 & -694.75 & 1.018 \\
\hline
\end{tabular}

Note: $\mathrm{R}^{2}$ = co-efficient of determination; RSE = Residual Standard Error; SEE = Standard Error of Equation; AICc = Akaike Information Criterion corrected; $\mathrm{CF}=$ Correction factor.

\subsection{Model Evaluation and Comparison}

The model efficiency and model prediction error values of the best-fitted TAGB models of the studies species were ranged from 0.845 to 0.913 (at scale 1) and $-1.336 \%$ to $8.474 \%$ respectively. The highest model efficiency and prediction error were observed for the $M$. azedarach, and $B$. acutangula, while the lowest model efficiency and model prediction error observed for the A. nilotica (Table 5). In comparison, the derived best-fit species-specific TAGB models have shown superiority than other frequently used pantropical and regional biomass models in relation to model efficiency and model prediction error (Table 5).

\section{Discussion}

The accuracy of allometric biomass model depends on some factors, such as, method of model development, model efficiency, selection of dependent and independent variables, and interpretation of outcomes (Picard et al., 2012; Sileshi, 2014). The present study tested linear regression equations, where the independent variables ( $D=$ Diameter at Breast Height, $H=$ Total height) and dependent variables (stem biomass and TAGB) were transformed to Ln (natural logarithm) to get best-fitted one for stem biomass and TAGB estimation. Best fit models are selected considering values of adjusted $\mathrm{R}^{2}$, RSE, AICc, and CF (Correction Factor) (West \& Wells, 1990; Parresol, 1999). In present study, models contained $D$ and $H$ as independent variables showed greater efficiency than models contained single variable, which was similar with the findings of the study of Rutishauser et al. (2013), Kusmana et al. (2018), and Khushi et al. (2019). The sample trees were collected from the same ecoregion hence wood density $(W)$ was not considered as another independent variable in the model development phase. However, $\mathrm{W}$ is not recommended as an independent variable for species-specific allometric models due to lack of robustness in use (Njana et al., 2016; Kusmana et al., 2018). Though models with single variable are easy to apply in the field but in case of model efficiency, application of multiple variables are more appreciated (Chave et al., 2014). 
Table 5. Comparison among the best fit TAGB models and frequently used pan-tropical and regional models.

\begin{tabular}{|c|c|c|c|c|c|c|c|c|c|c|c|c|}
\hline \multirow[t]{2}{*}{ Species } & \multicolumn{2}{|c|}{ Best-fit } & \multicolumn{2}{|c|}{$\begin{array}{c}\text { Brown } \\
\text { et al. (1989) }\end{array}$} & \multicolumn{2}{|c|}{$\begin{array}{l}\text { Nelson } \\
\text { et al. (1999) }\end{array}$} & \multicolumn{2}{|c|}{$\begin{array}{c}\text { Chave } \\
\text { et al. (2005) }\end{array}$} & \multicolumn{2}{|c|}{$\begin{array}{c}\text { Chave } \\
\text { et al. (2014) }\end{array}$} & \multicolumn{2}{|c|}{$\begin{array}{l}\text { Mahmood } \\
\text { et al. }(2019 a)\end{array}$} \\
\hline & ME & MPE (\%) & ME & MPE (\%) & ME & MPE (\%) & ME & MPE (\%) & ME & MPE (\%) & ME & MPE (\%) \\
\hline Acacia nilotica & 0.894 & 8.474 & 0.079 & 59.705 & -0.121 & 64.699 & 0.531 & 32.851 & 0.359 & 44.655 & 0.892 & 11.7102 \\
\hline Melia azedarach & 0.913 & -1.336 & -26.427 & 216.607 & -57.274 & 318.775 & -15.743 & 152.371 & -20.109 & 180.845 & -44.482 & 278.427 \\
\hline Barringtonia acutangula & 0.845 & 1.850 & 0.662 & -22.236 & 0.255 & 31.762 & 0.338 & -37.885 & 0.503 & -30.946 & 0.758 & 8.846 \\
\hline Casuarina equisetifolia & 0.892 & 1.869 & -0.943 & 68.794 & 0.543 & 24.612 & -0.357 & 44.122 & -0.582 & 54.922 & 0.877 & -21.561 \\
\hline Pongamia pinnata & 0.853 & 2.604 & -8.741 & 118.744 & -19.104 & 175.287 & -4.774 & 85.285 & -6.372 & 100.010 & -7.387 & 109.983 \\
\hline
\end{tabular}

Note: $\mathrm{ME}=$ Model efficiency, MPE $=$ Model prediction error.

Validation of the derived best fit model is an important aspect to check the model accuracy (Sileshi, 2014). A comparison is needed before the estimation of tree biomass by using the frequently used pantropical and regional allometric biomass models to maintain the realistic estimation of tree biomass (Mahmood et al., 2019a, 2019b, 2019c, 2020). Present study compared the derived TAGB models of the studied species with the pantropical and regional allometric biomass models in terms of model efficiency and model prediction error and indicated higher efficiency of the derived species-specific models. These variations in model accuracy may be related to some uncertainty related to species, wood density, geographical location, site quality, independent parameters in the models, which can limit the applicability of the biomass models beyond the study areas (Basuki et al., 2009; Alvarez et al., 2012; Manuri et al., 2014; Nam et al., 2016; Mahmood et al., 2019b). Thus present study recommended the application of best fit allometric biomass models for the studied species of Bangladesh instead of using other frequently used regional and pantropical models. Again the best-fitted models of present study require validation when they will be applied in different geographical locations.

\section{Conclusion}

Species-specific allometric biomass models with diameter at breast height $(D)$ and height $(H)$ as independent variables were best-fit models for the studied species. All the best-fitted allometric models showed higher model efficiency and lower model prediction error compared to the regional and pan-tropical models, which indicated that the derived best-fit TAGB model can efficiently and accurately estimate the biomass of the studied species. Therefore, it is suggested to use species-specific allometric models for biomass estimation for higher accuracy. In absence of species-specific models, ME and MPE need to be checked for the regional-and pan-tropical models to reduce uncertainties in large scale biomass estimation.

\section{Acknowledgements}

We greatly acknowledge the Bangladesh Forest Research Institute for the sharing 
of the volume data of the studied tree species. Finally, we like to thank Forestry and Wood Technology Discipline, Khulna University for their logistical supports.

\section{Conflicts of Interest}

The authors declare no conflicts of interest regarding the publication of this paper.

\section{References}

Alvarez, E., Duque, A., Saldarriaga, J., Cabrera, K., Delas Salas, G., Del Valle, I., Lema, A., Moreno, F., Orrego, S., \& Rodríguez, L. (2012). Tree Above-Ground Biomass Allometries for Carbon Stocks Estimation in the Natural Forests of Colombia. Forest Ecology and Management, 267, 297-308. https://doi.org/10.1016/j.foreco.2011.12.013

Basuki, T. M., van Laake, P. E., Skidmore, A. K., \& Hussin, Y. A. (2009). Allometric Equations for Estimating the Above-Ground Biomass in Tropical Lowland Dipterocarp Forests. Forest Ecology and Management, 257, 1684-1694. https://doi.org/10.1016/j.foreco.2009.01.027

Brown, S., Gillespie, A. J. R., \& Lugo, A. E. (1989). Biomass Estimation Methods for Tropical Forests with Applications to Forestry Inventory Data. Forest Science, 35, 881-902.

Chave, J., Andalo, C., Brown, S., Cairns, M. A., Chambers, J. Q., Eamus, D., Fölster, H., Fromard, F., Higuchi, N., Kira, T., Lescure, J. P., Nelson, B. W., Ogawa, H., Puig, H., Riéra, B., \& Yamakura, T. (2005). Tree Allometry and Improved Estimation of Carbon Stocks and Balance in Tropical Forests. Oecologia, 145, 87-99.

https://doi.org/10.1007/s00442-005-0100-x

Chave, J., Réjou-Méchain, M., Búrquez, A., Chidumayo, E., Colgan, M. S., Delitti, W. B., Duque, A., Eid, T., Fearnside, P. M., Goodman, R. C., Henry, M., Martínez-Yrízar, A., Mugasha, W. A., Muller-Landau, H. C., Mencuccini, M., Nelson, B. W., Ngomanda, A., Nogueira, E. M., Ortiz-Malavassi, E., Pélissier, R., Ploton, P., Ryan, C. M., Saldarriaga, J. G., \& Vieilledent, G. (2014). Improved Allometric Models to Estimate the Aboveground Biomass of Tropical Trees. Global Change Biology, 10, 3177-3190. https://doi.org/10.1111/gcb.12629

Das, D. K., \& Alam, M. K. (2001). Trees of Bangladesh. Chittagong: Bangladesh Forest Research Institute.

FAO (Food and Agricultural Organization of the United Nations) (2018). Global Forest Resources Assessment 2020: Terms and Definitions. Rome: FAO Forestry Department.

Genet, A., Wernsdorfer, H., Jonard, M., Pretzsch, H., Rauch, M., Ponette, Q., Nys, C., Legout, A., Ranger, J., Vallet, P., \& Saint-Andre, L. (2011). Ontogeny Partly Explains the Apparent Heterogeneity of Published Biomass Equations for Fagus sylvatica in Central Europe. Forest Ecology and Management, 261, 1188-1202. https://doi.org/10.1016/j.foreco.2010.12.034

GoB (Government of Bangladesh) (2019). Tree and Forest Resources of Bangladesh: Report on the Bangladesh Forest Inventory. Dhaka: Forest Department, Ministry of Environment, Forest and Climate Change, Government of the People's Republic of Bangladesh.

Hossain, M. K. (2015). Silviculture of Plantation Trees of Bangladesh (361 p.). Dhaka: Arannayk Foundation. 
Islam, S. A., Miah, M. A. Q., Habib, M. A., \& Moula, M. G. (2014). Performance of Some Mainland Trees and Palm Species Planted in the Coastal Islands of Bangladesh. Journal of Asiatic Society of Bangladesh, Science, 40, 9-15.

Ketterings, Q. M., Coe, R., Noordwijk, M. V., Amagau, Y., \& Palm, C. A. (2001). Reducing Uncertainty in the Use of Allometric Biomass Equations for Predicting AboveGround Tree Biomass in Mixed Secondary Forest. Forest Ecology and Management, 146, 199-209. https://doi.org/10.1016/S0378-1127(00)00460-6

Khushi, M. L. R., Mahmood, H., Abdullah, S. M. R., Saha, S., \& Siddique, M. R. H. (2019). Allometric Models for Estimation of Above-Ground Biomass of Gmelina arborea Roxb. in Pulpwood Plantations of Bangladesh. Southern Forests, 81, 45-48. https://doi.org/10.2989/20702620.2018.1488209

Kusmana, C., Hidayat, T., Tiryana, T., Rusdiana, O., \& Istomo (2018). Allometric Models for Above- and Below-Ground Biomass of Sonneratia spp. Global Ecology and Conservation, 15, e00417. https://doi.org/10.1016/j.gecco.2018.e00417

Latif, M. A., \& Islam, S. M. Z. (2014). Growth, Yield, Volume and Biomass Equation and Tables for Important Tress in Bangladesh. Chittagong: Forest Inventory Division, Bangladesh Forest Research Institute.

Mahmood, H., Siddique, M. R. H., Abdullah, S. M. R., Costello, L., Henry, M., Iqbal, M. Z., \& Akhter, M. (2019c). Which Option Best Estimates the above-Ground Biomass of Mangroves of Bangladesh: Pantropical or Site- and Species-Specific Models? Wetlands Ecology and Management, 27, 553-569. https://doi.org/10.1007/s11273-019-09677-0

Mahmood, H., Siddique, M. R. H., Abdullah, S. M. R., Saha, C., Islam, S. M. Z., Iqbal, M. Z., \& Akhter, M. (2020). Development and Evaluation of Species-Specific Biomass Models for Most Common Timber and Fuelwood Species of Bangladesh. Open Journal of Forestry, 10, 172-185. https://doi.org/10.4236/ojf.2020.101012

Mahmood, H., Siddique, M. R. H., Costello, L., Birigazzi, L., Abdullah, S. M. R., Henry, M., Siddiqui, M., Aziz, M., Ali, M., Mamun, A., Forhad, M., Akhter, M., Iqbal, M., \& Mondol, F. (2019a). Allometric Models for Estimating Biomass, Carbon and $\mathrm{Nu}-$ trient Stock in the Sal Zone of Bangladesh. iForest, 12, 69-75. https://doi.org/10.3832/ifor2758-011

Mahmood, H., Siddique, M. R. H., Islam, S. M. Z., Abdullah, S. M. R., Matieu, H., Iqbal, M. Z., \& Akhter, M. (2019b). Applicability of Semi-Destructive Method to Derive Allometric Model for Estimating Aboveground Biomass and Carbon Stock in the Hill Zone of Bangladesh. Journal of Forestry Research, 31, 1235-1245. https://doi.org/10.1007/s11676-019-00881-5

Manuri, S., Brack, C., Nugroho, N. P., Hergoualc'h, K., Novita, N., Dotzauer, H., Verchot, L., Putra, C. A. S., \& Widyasari, E. (2014). Tree Biomass Equations for Tropical Peat Swamp Forest Ecosystems in Indonesia. Forest Ecology and Management, 334, 241-253. https://doi.org/10.1016/j.foreco.2014.08.031

Mayer, D., \& Butler, D. (1993). Statistical Validation. Ecological Modeling, 68, 21-32. https://doi.org/10.1016/0304-3800(93)90105-2

Miah, M. D., Islam, K. N., Kabir, M. H., \& Koike, M. (2020). Allometric Models for Estimating Aboveground Biomass of Selected Homestead Tree Species in the Plain Land Narsingdi District of Bangladesh. Trees, Forests and People, 2, Article ID: 100035. https://doi.org/10.1016/j.tfp.2020.100035

Nam, V.T., Van Kuijk, M., \& Anten, N. P. R. (2016). Allometric Equations for Aboveground and Belowground Biomass Estimations in an Evergreen Forest in Vietnam. PLOS ONE, 11, e0156827. https://doi.org/10.1371/journal.pone.0156827 
Nandy, P., Haider, M. R., Islam, M. R., Alam, M. J., Moula, M. G., \& Habib, M. A. (2002). Growth Performance of 37 Species Raised in the Embankments of Eastern, Central and Western Coastal Belts of Bangladesh. Research Bulletin (p. 41). Coastal Greenbelt Project, Dhaka: Bangladesh Forest Department.

Návar, J. (2009). Allometric Equations for Tree Species and Carbon Stocks for Forests of North Western Mexico. Forest Ecology and Management, 257, 427-434. https://doi.org/10.1016/j.foreco.2008.09.028

Nelson, B. W., Mesquita, R., Pereira, J. L. G., Souza, S. G. A. D., Batista, G. T., \& Couto, L. B. (1999). Allometric Regressions for Improved Estimate of Secondary Forest Biomass in the Central Amazon. Forest Ecology and Management, 117, 149-167. https://doi.org/10.1016/S0378-1127(98)00475-7

Njana, M. A., Meilby, H., Eid, T., Zahabu, E., \& Malimbw, R. E. (2016). Importance of Tree Basic Density in Biomass Estimation and Associated Uncertainties: A Case of Three Mangrove Species in Tanzania. Annals of Forest Science, 73, 1073-1087. https://doi.org/10.1007/s13595-016-0583-0

Parresol, R. (1999). Assessing Tree and Stand Biomass: A Review with Examples and Critical Comparisons. Forest Science, 45, 573-593.

Picard, N., Saint-André, L., \& Henry, M. (2012). Manual for Building Tree Volume and Biomass Allometric Equations: From Field Measurement to Prediction. Rome, Montpellier: Food and Agricultural Organization of the United Nations and Centre de Coopération Internationale en Recherche Agronomique pour le Développement.

Potapov, P., Siddiqui, B., Iqbal, Z., Aziz, T., Zzaman, B., Islam, A., Pickens, A., Talero, Y., Tyukavina, A., \& Turubanova, S. (2017). Comprehensive Monitoring of Bangladesh Tree Cover Inside and Outside of Forests, 2000-2014. Environmental Research Letters, 12, Article ID: 104015. https://doi.org/10.1088/1748-9326/aa84bb

Rutishauser, E., Noor'an, F., Laumonier, Y., Halperin, J., Rufi'ie, Hergoualc'h, K., \& Verchota, L. (2013). Generic Allometric Models Including Height Best Estimate Forest Biomass and Carbon Stocks in Indonesia. Forest Ecology and Management, 307, 219-225. https://doi.org/10.1016/j.foreco.2013.07.013

Siddiqi, N. A. (2002). Development and Sustainable Management of Coastal Plantations in Bangladesh. Journal of Asiatic Society of Bangladesh, Science, 28, 144-166.

Sileshi, G. W. (2014). A Critical Review of Forest Biomass Estimation Models, Common Mistakes and Corrective Measures. Forest Ecology and Management, 329, 237-254. https://doi.org/10.1016/j.foreco.2014.06.026

Sprugel, D. G. (1983). Correcting for Bias in Log-Transformed Allometric Equations. Ecology, 64, 209-210. https://doi.org/10.2307/1937343

Ter-Mikaelian, M. T., \& Korzukhin, M. D. (1997). Biomass Equations for Sixty-Five North American Tree Species. Forest Ecology and Management, 97, 1-24. https://doi.org/10.1016/S0378-1127(97)00019-4

West, P. W., \& Wells, K. F. (1990). Estimation of Leaf Weight of Standing Trees of Eucalyptus Regnans. Canadian Journal of Forestry Research, 20, 1732-1738.

https://doi.org/10.1139/x90-230

Zanne, A. E., Lopez-Gonzalez, G., Coomes, D. A., Ilic, J., Jansen, S., Lewis, S. L., Miller, R. B., Swenson, N. G., Wiemann, M. C., \& Chave, J. (2009). Global Wood Density Database. 